\title{
Imperializm, kolonializm, globalizm: stare idee, nowe wyzwania*
}

\begin{abstract}
Imperialism, colonialism, globalism: old ideas, new challenges. The article arises from observations on the terminological inadequacy pertaining to today's reality, and from the analysis of the consequences of using prefixes "neo-" and "post-". It thereby indicates the need to focus on the question of extending life and on the ideational influence of progressive doctrines as causes of the poverty of reflection on new terminology appropriate to contemporary challenges. In the face of the ever-evolving world, that terminology may be sought in a systemic approach.
\end{abstract}

Keywords: Imperialism, colonialism, globalism, terminology, idea

„Porwie nas tylko Europa, która będzie jednocześnie ideą"1

Idee dawne, ujęte w pojęciach głęboko ugruntowanych w naszym doświadczeniu poznawczym, muszą sprostać wyzwaniom coraz to nowym. Ten stan rzeczy jest dla nas oczywisty, podobnie jak towarzysząca mu trauma. Problem pojawia się, gdy

${ }^{*}$ E-mail: jotka8@gmail.com.

** Referat wygłoszony na konferencji „Neoimperializm, neokolonializm i dyskurs neokolonialności w postkomunistycznych kulturach i literaturach Europy Środkowej, Wschodniej i Południowo-Wschodniej”, Wojnowice 8 czerwca 2018 roku. Wyrażam serdeczne podziękowania uczestnikom za okazane zainteresowanie i pożyteczną dyskusję wykorzystaną w przygotowaniu ostatecznej wersji.

${ }^{1}$ T. Todorov, Nowy nieład światowy. Refleksje Europejczyka, Warszawa 2003, s. 123. 
stając wobec nowego wyzwania, nabieramy wątpliwości co do przydatności naszego „oprzyrządowania”2.

Terminy używane w europejskich opisach świata zawsze były narzędziem kontroli, przekształcały poznawaną rzeczywistość przez jej werbalne podporządkowa$n^{3}{ }^{3}$. W rezultacie jednak staliśmy się niewolnikami naszych pojęć. W każdym razie my, ludzie cywilizacji europejskiej. Cechą tej cywilizacji było staranie, by nadążać za zmieniającą się rzeczywistością, stale aktualizując - czy wręcz tworząc nową siatkę pojęć. Gdy brak nam nowych idei, stając wobec nowych wyzwań, usiłujemy dostosować nasz aparat pojęciowy za pomocą znaczących przedrostków, na przykład właśnie „neo-” i „post-”. Wśród tych terminów znalazły się neoimperializm i postkolonializm.

Terminologia nasza jest więc rodem $\mathrm{z}$ wieku XIX - epoki panowania ideologii, czasu gdy Europa, stając się Zachodem, podbijała świat i tworzyła go wedle własnego projektu. Imperializm i kolonializm, ale także nacjonalizm, socjalizm, anarchizm, komunizm, liberalizm, modernizm i ewolucjonizm tworzyły siatkę pojęciową porządkującą świat przed I wojną światową ${ }^{4}$. Po katastrofie, jaką był ten konflikt, i po rewolucji $-\mathrm{w}$ istocie europejskiej, choć noszącej nazwę bolszewickiej lub rosyjskiej - ukształtowały się nowe pojęcia takie jak faszyzm i nazizm, a nowego sensu nabrały terminy rasizm i antysemityzm. Między dwiema wojnami upowszechniły się też pojęcia przeciwstawne, $\mathrm{z}$ których największą karierę zrobiły antyfaszyzm i antykolonializm. Sam fakt ciągłości, dziedziczenia i rozwijania siatki pojęć jest zrozumiały, a w Europie traktowany jako norma. Nie wynika z tego skuteczność.

Druga wojna światowa była wprawdzie kontynuacją poprzedniej, ale miała zupełnie inny wpływ na zasób pojęć. Szło o dużo więcej niż tylko o skorygowanie ustaleń z Wersalu; ten konflikt miał sens rewolucyjny, oznaczał ostateczną przebudowę porządku światowego ustalonego w wieku XIX. Jedną z konsekwencji była ideologizacja, nowy porządek światowy ustalały nie tylko mocarstwa, lecz także ludy włączające się do stanowienia o sobie. Dzięki temu rewolucja utrwaliła swój pozytywny wizerunek jako droga wolności i nowoczesności. Stąd słownik powojenny wzbogacał się o takie pojęcia jak denazyfikacja i dekolonizacja. Zanim ogłoszono koniec wieku ideologii, powstał nowy słownik, w którym zaznaczyły się terminy takie jak neokolonializm, neoimperializm, ale także neoliberalizm. Były one, zauważmy, pochodną ideologizacji stosunków w świecie powojennym, który przyjął postać geopolitycznego trójpodziału. $\mathrm{W}$ drugiej połowie $\mathrm{XX}$ wieku mieliśmy trzy

2 Por. Reinharta Kosellecka rozważanie nad implikacjami zmiany znaczeń pojęć, poczynając od „Historia pojęć i pojęcie historii”, [w:] idem, Dzieje pojęć. Studia z semantyki i pragmatyki języka społeczno-politycznego, Warszawa 2009, s. 56 n.

3 Dotyczy to także nazewnictwa miejscowego, por. J. Kieniewicz, „Identifying local people: a colonial and postcolonial practice in Central Asia", [w:] Facing challenges of identification. Investigating identities of Buryats and their neighbor peoples, t. 3, red. I. Peshkov, K. Wielecki, Warszawa 2020, s. 33-47.

${ }^{4}$ Znaczenie Wielkiej Wojny jako zamknięcia długiego (europejskiego) wieku XIX podkreśla Jurgen Osterhammel, Historia XIX wieku. Przeobrażenie świata, Poznań 2013. 
światy, których istnienie i nazwanie zawdzięczamy raczej ideologom niż procesom samostanowienia. To wywarło silny wpływ na upowszechniającą się i coraz bardziej globalną nomenklaturę.

W dobie zimnej wojny każdy z trzech światów wytwarzał własny zasób pojęć, nawet wtedy, gdy używano tych samych słów. Chaos pojęciowy narastał wraz z petryfikacją układu sił. Te nowe znaczenia dla dotąd uniwersalnych terminów wynikały z ideologizacji konfliktów. Dywersja ideologiczna dawała o sobie znać przede wszystkim w naukach politycznych i społecznych, ale inwazja środków masowego przekazu rozpowszechniła obcowanie z pojęciami coraz bardziej oderwanymi od jakiejkolwiek rzeczywistości. Jeszcze w okresie między wojnami zdano sobie sprawę ze znaczenia propagandy, która ogarnęła także sferę akademicką. Po 1945 uniwersytety znalazły się na pierwszej linii ideologicznej konfrontacji. Jak wiadomo, afiliacje ideowe szły wtedy w poprzek podziałów politycznych. Zimna wojna była więc bardzo gorącym starciem w sferze idei, zwłaszcza na uniwersytetach i wszędzie tam, gdzie istniała jakaś swoboda myślenia i wypowiedzi. Konwergencja światów nie oznaczała uzgodnienia w sferze pojęć.

Nowy sens zyskały w drugiej połowie XX wieku takie pojęcia jak fundamentalizm, ale także kapitalizm i socjalizm, humanizm czy ekumenizm. Rzeczą szczególną, a dla tych rozważań podstawową, było uzmysłowienie sobie wtedy wielości ścieżek rozwoju, wyjście poza schemat dwu dróg. Mam na myśli środowisko akademickie ówczesnej Polski, ale zjawisko wydaje mi się powszechne. Klęska ekonomicznej postaci socjalizmu wydawała się sprzyjać uproszczeniu wizji, ogłoszeniu końca nie tylko wieku ideologii, ale także historii jako opowieści o ewolucji człowieka ${ }^{5}$. Rzecz okazała się bardziej złożona, a to za sprawą globalizacji. Wprawdzie usiłowano dowodzić, że nie jest to całkiem nowe zjawisko, ale zanim je w pełni rozpoznano, dotychczasowe narzędzia opisu i analizy okazały się nieadekwatne. Globalizacja okazała się określeniem niewystarczającym do wyjaśnienia nowego porządku rzeczy, który ukształtował się na przełomie stuleci ${ }^{6}$. Bardzo szybko przestała opisywać stan gospodarki światowej i charakteryzować przepływy finansowe i informacyjne ${ }^{7}$. Została natomiast obciążona odpowiedzialnością nie tylko za nierówność podziału korzyści z postępu, ale także za nierównomierne obciążenie konsekwencjami kryzysu ekologicznego. Wydaje się, że w znacznej mierze przyczyniła się do niepowodzeń dążeń transformacyjnych podejmowanych po upadku komunizmu w krajach dawnego bloku sowieckiego. Nie identyfikowały się już z „drugim światem”, a ich

${ }^{5}$ Francis Fukuyama w latach dziewięćdziesiątych proponował widzenie sensu historii jako jednolitego procesu ukierunkowanego ewolucyjnie, ale nie zaproponował nowej terminologii (Koniec historii, Kraków 2009). Dostrzegał jednak ten problem, gdy zajął się perspektywą człowieka (Koniec człowieka. Konsekwencje rewolucji biotechnologicznej, Kraków 2004).

6 Z. Bauman, Globalizacja. I co z tego dla ludzi wynika, Warszawa 2000.

7 Zwracał na to uwage Immanuel Wallerstein, The end of the world as we know it. Social science for the twenty-first century, Minneapolis-London 1999. Wallerstein jako jeden z nielicznych skonstruowat siatkę pojęć opisującą systemy-światy, por. idem, Analiza systemów-światów. Wprowadzenie, Warszawa 2007. 
aspiracje do znalezienia się w pierwszym zostały brutalnie zweryfikowane $e^{8}$. To znalazło odzwierciedlenie w używanym nazewnictwie.

Opisanie, a więc i zrozumienie epoki po 1989 roku wymaga zatem nowej terminologii. Na razie jej brak. Dzieje się tak nie tylko z powodu złożoności świata sieciowego, globalności rynków i świadomości zagrożeń ekologicznych. Trudność wyrażenia się tkwi w naszym aparacie pojęciowym. Podlegał on gwałtownym przemianom co najmniej w ostatnim półwieczu, a to pod wpływem rewolucji roku 1968. Ona wyniosła bowiem na szczyty kontrkulturę mającą ambicję przeciwstawienia się kontrrewolucji. Humanistyka, starając się nadrobić straty spowodowane ideologizacją pierwszej połowy wieku XX, dokonała niezliczonych zwrotów ${ }^{9}$, a zabiegając o uznanie statusu naukowego, weszła w nurt zaznaczony przedrostkami „post-”, „trans-" i „kontr-”. O ile początkowo znaczyły tylko po, przez i przeciw, o tyle z czasem przybrały sens jakby nowego podejścia metodologicznego. Widać to najwyraźniej w losach pojęcia „postkolonializm” ${ }^{10}$, które objęło spektrum znaczeń, włącznie z koncepcją ideową i doktryną polityczną ${ }^{11}$, a także w bliskim mu określeniu „postdependentyzm” 12 . Oba terminy zagościły w dyskursie akademickim w epoce PRL, ale przybrały swoistą postać ${ }^{13}$. Podobnie rzecz się miała z postkomunizmem, który w Polsce po 1989 roku przyjął się jako określenie rzeczywistości raczej niż jako przeciwstawienie dla antykomunizmu ${ }^{14}$. Dekonstrukcjonizm zdominował epokę po wielkim zwrocie kontrkultury, nadał nowy wdzięk dawnym pojęciom, takim jak

${ }^{8}$ Mówił o tym gorzki dowcip z tamtych lat: „Mieliśmy zbudować Trzecią Polskę, zbudowaliśmy Trzeci Świat w Polsce".

9 D. Bachmann-Medick, Cultural Turns. Nowe kierunki w naukach o kulturze, Warszawa 2012.

10 Najpełniejsza prezentacja polskiej perspektywy przez Bogusława Bakułę, „Europa Środkowo-Wschodnia i jej (post)kolonialny świat", [w:] Dyskurs postkolonialny we współczesnej literaturze i kulturze Europy Środkowo-Wschodniej. Polska, Ukraina, Wegry, Stowacja, red. B. Bakuła et al., Poznań 2015, s. 13-97. Zob. też A. F. Kola, Socjalistyczny postkolonializm. Rekonsolidacja pamięci, Toruń 2018.

11 R.J.C. Young, Postkolonializm. Wprowadzenie, Kraków 2012. O wielości pojęć pisze obszernie Ania Loomba, Kolonializm/postkolonializm, Poznań 2011; fundamenty teoretyczne przedstawia Leela Gandhi, Teoria postkolonialna. Wprowadzenie krytyczne, Poznań 2008, gdzie w posłowiu Ewa Domańska zwraca uwagę na ideowe implikacje terminologii, s. 157-165.

$12 \mathrm{~W}$ języku polskim od dawna przyjęło się określenie „zależność”, stąd mamy studia czy koncepcje postzależnościowe. Zob. H. Gosk, „Krytyka postzależnościowa - polska odmiana studiów postkolonialnych", [w:] Perspektywy postkolonializmu w Polsce, Polska w perspektywie postkolonialnej, Debaty Artes Liberales, t. 10, red. J. Kieniewicz, Warszawa 2016, s. 57. Zob. też inne prace tej autorki i Centrum Badań Dyskursów Postzależnościowych.

13 Polegało to moim zdaniem na „oswajaniu” terminologii zachodniej przez odwoływanie się do autorów o orientacji lewicowej czy postępowej, przede wszystkim latynoamerykańskich. Przejmowanie to $\mathrm{w}$ wielu wypadkach było szczere, wśród zajmujących się problematyką trzecioświatową w Polsce przeważała skłonność lewicowa, choć niekoniecznie prokomunistyczna. Postawy te były tolerowane w dość wyczuwalnych granicach wyznaczanych czymś, co nazywano „pryncypiami ustrojowymi”. Temat ten wydaje mi się słabo obecny w studiach nad historiografią tamtych lat (Sosnowska, Siewierski), a wart jest zastanowienia.

${ }^{14}$ Zob. teksty w tomie Antykomunizm po komunizmie, red. J. Kloczkowski, Kraków 2000. 
dekadentyzm, konsumpcjonizm, a na koniec infantylizm ${ }^{15}$. Natomiast jedno z najstarszych pojęć uniwersalnych, czyli „humanizm”, uległo degradacji ze względu na przypisanie mu sensu antropocentrycznego czy wręcz maskulinistycznego. Widać to wyraźnie w użyciu pojęć „posthumanizm” i ,transhumanizm”"16. Przedrostek ,kontr-” nie zyskał tak szerokiego zastosowania, do wyrażenia sprzeciwu pozostawano przy przedrostku „anty-”. Kolosalną karierę przedrostek „trans-” wydaje się zawdzięczać zastosowaniu w opisie zjawisk kontrkulturowych preferujących przekraczanie granic $^{17}$.

Jedynym ważnym pojęciem wyłamującym się z tego trendu jest „orientalizm”, $\mathrm{w}$ mniejszym zakresie okcydentalizm i jego pochodne ${ }^{18}$. Jest to następstwo szczęśliwego zbiegu wypadków. Edward Said użył określenia znanego od stuleci dla dotąd zdefiniowanej rzeczywistości czyli uznawania przez podporządkowanych opinii wytworzonych przez narzucających im swe panowanie. Jak wiadomo, odnosił się bardzo konkretnie do mieszkańców tak zwanego Bliskiego Wschodu, czyli klasycznego Orientu ${ }^{19}$. Bardzo ostrożnie podchodził do rozciągania jego koncepcji na inne obszary Azji poddane panowaniu kolonialnemu ${ }^{20}$.

W wieku XXI poszukiwanie nowych pojęć nie przyniosło wyraźnych skutków. Ani kryzysy gospodarki rynkowej, ani geograficzne przesunięcia potęgi nie spowodowały ukształtowania nowej terminologii. Ekologizm nie zyskał znaczenia stosownego do wagi zagrożeń biosfery, gwałtowne rozpowszechnienie uczestnictwa w mediach społecznościowych nie owocowało jakąśs nową terminologią. Owszem, nowego znaczenia nabrał stary termin "feminizm”. Jeszcze starszy „patriotyzm” podlegał w ostatnich dwu stuleciach tak mocnym przekształceniom, że zaczął popadać w zapomnienie. Nacjonalizm ma natomiast coraz szersze zastosowanie, choć narody zdają się anachroniczną formą społecznego zrzeszenia. Pojawiła się za to na przełomie tysiącleci wizja odnowy kosmopolityzmu jako swego rodzaju odpowiedź na multikulturalizm. Rozbudowane nurty antyortodoksyjne w zakresie relacji seksualnych, odżywiania, muzykowania nie zaowocowały jeszcze powszechnie przyjętą terminologią. W zasadzie procesy przekształceń mające na celu skuteczną

15 B.R. Barber, Skonsumowani. Jak rynek psuje dzieci, infantylizuje dorostych i polyka obywateli, Warszawa 2008, r. I.

16 M. Bakke, „Posthumanizm: człowiek w świecie większym niż ludzki”, [w:] Człowiek wobec natury - humanizm wobec nauk przyrodniczych, red. J. Sokólski, Warszawa 2010, s. 337-357.

17 J. Guzowski, „Transhumanizm - eskapizm czy wizjonerstwo?”, Szkice Humanistyczne 14, 2014, nr 1(2), s. 89-105; K. Szymański, „Transhumanizm”, Kultura i wartości 2015, nr 13, s. 133-152.

18 I. Buruma, A. Margalit, Okcydentalizm. Zachód w oczach wrogów, Kraków 2005. Ale mamy liczne inne rozumienia tego terminu, a także postokcydentalizm lansowany przez Waltera Mignolo, "Posoccidentalismo: las epistemologías fronterizas y el dilema de los estudios (latinoamericanos) de área”, Revista Iberoamericana 68, 2002, nr 200. Zob. prezentację tego zagadnienia przez Filipa Kubiaczyka, Nowoczesność, kolonialność i tożsamość: perspektywa latynoamerykańska, Poznań 2013, s. 52-60.

19 E. Said, Orientalism, New York 1978. Jego dzieło przechodziło transformacje między 1978 a 1995, a jeszcze mocniej oddziałały narastające wokół interpretacje.

20 S. Walia, Edward Said y la historiografía, Barcelona 2004. 
modernizację i demokratyzację okazały się mało skuteczne, między innymi właśnie ze względu na globalizację.

Tymczasem zmiany w świecie przyspieszają, a to zawsze znaczy, że nie znajdują się pod kontrolą, że nie umiemy nimi sterować ${ }^{21}$. Całkowicie zmieniła się w XXI wieku komunikacja - szybkość, z jaką następuje, utrudnia ukształtowanie powszechnie stosowanej terminologii. Chcę powiedzieć, że nasze myślenie nie nadąża, czyli nie zostało jeszcze przetworzone przez nowe technologie ${ }^{22}$. Może to i lepiej, ale zmiany społeczne, obyczajowe, ekologiczne nie mogą być obsłużone w sposób, do którego przyzwyczaiły nas poprzednie epoki. Świat sieci został już dokładnie opisany ${ }^{23}$, wytworzył nawet własną religię $\mathrm{w}$ postaci dataizmu ${ }^{24}$.

Tak więc usiłujemy coraz to nowe wyzwania obsłużyć starymi pojęciami. Czy stoimy przed istotnym problemem? Dodajmy, że zauważenie nowości i odczytanie charakteru wyzwań wcale nie jest oczywiste. W procesie tym bowiem ogromną rolę odgrywa aparat pojęciowy dostarczony przez nauki zajmujące się człowiekiem i jego światem ${ }^{25}$. Postrzeganie nowości zjawiska, uznanie go za wyzwanie, nie jest ani oczywiste, ani automatyczne. Zależy od naszego aparatu pojęciowego, który w dodatku wyrósł z badań empirycznych przeprowadzonych w świecie cywilizacji euro-amerykańskiej, zwanej potocznie zachodnią.

Z całą pewnością $w$ dzisiejszym świecie nadal mamy do czynienia z dążeniem do narzucania innym swej władzy, interesu czy kultury. Bez wątpienia znajdziemy przypadki przyjmowania zewnętrznej dominacji i podporządkowania się obcym interesom. Jest też dość oczywiste, że w świecie przeważa skłonność do stawiania interesów ogólnych nad indywidualnymi. Dla wielu są to wystarczające powody dla stosowania trzech tytułowych pojęć jako najlepiej odpowiadających naszym potrzebom.

Współczesne wyzwania da się opisać w trzech blokach.

1. Eskalacja konfliktów, której wyrazem są wojny nazwane hybrydowymi, ponieważ nie toczą się wedle dawniej uznanych norm. Konsekwencjami są terroryzm, migracje, destabilizacja.

2. Wszechogarniająca sieć tworząca świat przyspieszonej komunikacji i pogłębiającej się alienacji. Jej podstawowym desygnatem jest informacjonizm, a wartością nadrzędną bezpieczeństwo.

21 To znaczy, wydaje nam się, że potrafimy. Zob. H.P. Martin, H. Schumann, Pułapka globalizacji. Atak na demokrację i dobrobyt, Wrocław 2000.

22 O konsekwencjach, także nazewnictwa, pisali wielokrotnie Alvin i Heidi Tofflerowie, Budowa nowej cywilizacji. Polityka trzeciej fali, Poznań 1996, a także Amartya Sen, Rozwój i wolność, Poznań 1999.

${ }^{23}$ M. Castells, Wiek informacji: ekonomia, społeczeństwo i kultura, t. 1. Społeczeństwo sieci, Warszawa 2007.

24 Prezentację nowej wiary daje Steve Lohr, Data-ism: the revolution transforming decision making, consumer behavior, and almost everything else, New York 2015.

${ }^{25}$ U. Beck, Społeczeństwo światowego ryzyka. W poszukiwaniu utraconego bezpieczeństwa, Warszawa 2012. 
3. Kryzys ekologiczny i kryzys wartości, które zbiegły się z nową fazą gospodarowania, gdzie żaden z podmiotów nie jest tym, czym był pierwotnie: rynek, kapitał, zasoby, siła robocza. W efekcie mamy terminologiczny śmietnik: outsourcing.

Wszystkie trzy zdają się spotykać w próbie przewidzenia przyszłości jako ucieczki od śmierci ku utopii wiecznego życia w nowej, postludzkiej postaci.

Spróbujmy opisać stan świata wymienionych wyzwań, nie odwołując się do tytułowych pojęć: „imperializm”, „kolonializm”, „globalizacja”. Możemy oczywiście postąpić odwrotnie - tak zredefiniować pojęcia, by odpowiadały nowym okolicznościom. W swoim czasie przeprowadziłem taką operację, usiłując określić, czym był kolonializm w epoce „ekspansji i dominacji”26. Jak wiadomo, z ograniczonym sukcesem. Teraz jednak oznaczałoby to swego rodzaju dreptanie w miejscu.

Świat stworzony przez człowieka pozostaje naznaczony dominacją europejską, choć potęga Europy skończyła się przed stu laty. Proporcje demograficzne odwróciły się i mocarstwami stały się kraje wyrosłe z innych cywilizacji. Równocześnie paradygmat „polityki światowej” pozostał nienaruszony. Potęgi kwestionujące układ sił odwołują się do zasad i porządków ustanowionych w epoce europejskiej, a potem amerykańskiej hegemonii. Kraje aspirujące do pozycji mocarstw, kraje kwestionujące dotychczasowe „hierarchie” nie wydają się rewolucjonizować ładu światowego (co było ambicją ZSSR). Aspiracje do przywództwa regionalnego czy światowego nie kwestionują podstaw porządku politycznego. Odnosi się to także do sfery kultury: westernizacja była długo utożsamiana z modernizacją, świat nowoczesny miał stawać się homogeniczny. Zmniejszająca się różnorodność kultur towarzyszyła uniformizacji w sferze zachowań. Nie znaczy to jednak, że ludzie oderwali się od dawnych przyzwyczajeń. Pojęcia należą do sfery kultury, ale można też je precyzyjniej usytuować w zasobie służącym społeczeństwom do przeprowadzania zmian.

Rozpatrując kwestię potęgi, rywalizacji i dominacji w skali regionalnej, zauważamy, że zaszły o wiele głębiej sięgające zmiany. Pozornie nadal chodzi o rywalizację o terytorium, zasoby materialne, narzucenie własnego rozwiązania politycznego, a więc o tradycyjne aspiracje państw. Nowe jest przecież gwałtowne rozszerzenie skali podmiotów aspirujących do uzyskania statusu państwowego. Z jednej strony „państwa upadłe”, z drugiej ISIS czy rozliczne „partyzantki”. Do tego dodać trzeba organizacje przestępcze, kartele narkotykowe i pozbawione struktur terytorialnych ugrupowania terrorystyczne. Porządek światowy jest zachwiany bardziej niż kiedykolwiek. Próby zaprowadzenia ładu światowego prowadzą do kolejnych katastrof humanitarnych, nie wspominając o stratach materialnych. Walki o panowanie i kontrolę - na razie głównie zasobów energetycznych, ale potencjalnie także rezerw wody pitnej - rodzą brak zaufania i uniemożliwiają podejmowanie decyzji w skali globalnej. Zidentyfikowane zagrożenia w rodzaju globalnego ocieplenia, zatrucia oceanów, wymierania gatunków i erozji gleb, pozostają abstrakcją nawet wtedy, gdy

${ }^{26}$ J. Kieniewicz, Od ekspansji do dominacji. Próba teorii kolonializmu, Warszawa 1986. 
lokalnie dotykają konkretnej społeczności. Świadomość ekologiczna nie przekłada się na wolę zmiany politycznej.

Zmiany zaznaczają się silniej w przestrzeni społecznej. Brak konsensu w sprawie demografii i konsumpcji, na żadnym poziomie nie ma zgody co do kierunku ewolucji stosunków wytwarzania i podziału. Rewolucja informatyczna nie pociągnęła za sobą zmiany społecznej - przeciwnie, odnosi się wrażenie osłabienia więzi wspólnotowych. Konflikty na tle religijnym, etnicznym i ekonomicznym przesłaniają istotę obecnego kryzysu. Postawą dominującą stają się narcyzm i eskapizm wyrażane w coraz to nowych projektach ideologicznych. Wiedza o niemożności dokonania zmiany nie zyskała nazwy i nie ma własnego aparatu pojęciowego.

Można odnieść wrażenie, że bezradność wobec coraz szybciej zmieniającej się rzeczywistości, poczucie braku wpływu skutkują odwołaniem się do sfery lepiej kontrolowanej, jaką jest nauka. Z rozmachem powstają projekcje przyszłości zakładające udoskonalenie człowieka ${ }^{27}$. Wierzymy w nie coraz bardziej, bo nie znajdujemy wzoru zmiany zdolnego sprostać coraz lepiej identyfikowanym zagrożeniom ${ }^{28}$. Perspektywy oferowane przez rozwój medycyny odwracają uwagę od problemów globalnych. To, wydaje mi się, blokuje inwencję w budowaniu aparatury pojęciowej odpowiedniej do obecnych wyzwań.

Z tych racji poszukiwanie i znajdowanie pojęć stosownych do rozpoznania i oceny zjawisk zachodzących $\mathrm{w}$ społeczeństwie, $\mathrm{w}$ jego relacjach ze środowiskiem i z otoczeniem $^{29}$, jest obarczone ogromnym ryzykiem. Nie wiemy, kto jest powołany do wskazywania stosownych pojęć, nie jest jasne, jak pojawiające się propozycje zyskują uznanie, stając się akceptowaną narracją i kodem kulturowym. Niepewność pogłębia wspomniana wcześniej zależność ustaleń psychologii od ich kulturowo jednostronnej podstawy. Zagrożenia wymagają nazwania, by można było im sprostać. Jeszcze wyraźniej deficyt dostępnych narracji daje się odczuć, gdy stajemy wobec wyzwania, jakim jest kształtowanie polityki na przyszłość. Czy jesteśmy wobec tego bezradni? Czy pozostaje nam oczekiwanie na spontaniczne kształtowanie się pojęć opisujących rzeczywistość w sposób przynoszący nadzieję na znalezienie rozwiązań? Z całą pewnością nie wystarczy nadzieja na to, że zasób, który obecnie mamy do dyspozycji, potrafi adaptować się do nowych zadań.

Te dwa zakresy działań mają znaczenie podstawowe. Problem z tym, że nasze uzależnione od doświadczenia wyobrażenia i projekty są z natury zachowawcze. Można powiedzieć, że obrona tożsamości systemu potrafi skutecznie blokować próby nowych transformacji ${ }^{30}$. Dopiero w trzecim ze wspomnianych bloków spoty-

27 Y.N. Harari, Homo Deus. Krótka historia jutra, Kraków 2018.

28 Próbowałem wskazać na pewne implikacje J. Kieniewicz, „Ekohistoryk wobec wyzwań przyszłości", Przegląd Humanistyczny 2014, nr 1, s. 65-80.

${ }^{29} \mathrm{~W}$ rozumieniu nadawanym w General Systems Theory.

${ }^{30}$ Rozwijam tę kwestię w J. Kieniewicz, „Experiences in searching for the identity of a nation", [w:] Searching for identity: personal experiences and methodological reflections, red. A. Zhanaev, O. Tkachenko, Warszawa 2021, s. 23-35. 
kamy okoliczności wymuszające innowacje. Globalizacja jest próbą opisania rzeczywistości, w której każdy znajduje się w związku z całością. Rewolucja informatyczna wprowadziła nieznaną dotąd szybkość przepływu informacji, co doprowadziło do zasadniczych zmian w funkcjonowaniu rynków, ale także do ustalenia nowego typu relacji między ludźmi. $Z$ tego jak dotąd nie wynikła żadna praktyka rokująca podjęcie skutecznych kroków w stronę zahamowania kryzysów: demograficznego i ekologicznego. Pojawiają się natomiast kolejne konstrukcje mające opisać los człowieka i jego perspektywy ${ }^{31}$. Prym wiodą propozycje określone jako posthumanistyczne, będące w istocie kontynuacją antropocentrycznego myślenia.

Nie jestem w posiadaniu innego, skuteczniejszego kodu nazywającego współczesny świat, mogącego dać nam uzdolnienie do czegoś więcej niż reagowanie na zjawiska, które już wystąpiły. Z praktyki wiemy, że te reakcje są zawsze spóźnione, a często nietrafione. Mam tylko jedną intuicję.

Wszystkie obecnie powstające formy: „neo-", , ,anty-”, „post-”, „trans-”, „kontr-”, „sub-" mają jedną wspólną właściwość - ich celem jest podtrzymanie wrażenia ciągłości w świecie zupełnie nieliniowym. Całe nasze myślenie, pomimo zwrotów i przewrotów we wszelkich dziedzinach, opiera się na idei ciągłości ${ }^{32}$. Tymczasem powinno stać się kompleksowe ${ }^{33}$. Szanse na racjonalne działania wspólnot wolnych obywateli znacząco by wzrosły, wspierane praktycznie zorientowanym myśleniem, czyli spójnym systemem pojęć ${ }^{34}$. Zdaję sobie oczywiście sprawę z utopijnego charakteru tego postulatu. Przyszłość, jeśli mamy ją planować, może oprzeć się na zrozumieniu procesów, które doprowadziły nas do obecnego stanu. Wiedza o przeszłości nie determinuje wprawdzie scenariusza teraźniejszości, ale może stać się materiałem do budowania projektów na przyszłość. Taki globalny projekt wydaje się niezbędny, ale wymaga dojścia do porozumienia. A porozumienie zakłada komunikację i wspólnotę nie tylko kodów, ale także interesów.

Reasumując, podstawowe pojęcia opisujące świat nie tylko mogą, lecz wręcz powinny być zrewidowane. Adaptacja imperializmu, kolonializmu i globalizmu do potrzeb współczesności jest oczywiście możliwa, ale zaspokaja co najwyżej ambicje akademickie. Dając nowy sens starym pojęciom, uzyskujemy kojące poczucie ciągłości i wrażenie kontroli, będące jednymi z warunków poczucia bezpieczeństwa. Nie zyskujemy jednak w ten sposób narzędzi pozwalających na coś więcej, a mianowicie na przeprowadzenie koniecznych zmian. Powtórzę: uciekamy od podstawowych problemów w sferę efektownych konstrukcji i ekscytujących marzeń. Uważam wręcz, że te pojęcia i ich awatary - „post-” lub „neo-” - zaciemniają obraz tak potrzebny do sformułowania konkretnego projektu przyszłości. Wydaje mi się, że

31 T.H. Erikson, Tyrania chwili. Szybko i wolno plynacy czas w erze informacji, Warszawa 2003.

32 Debatę nad tym prowadzi Stephen J. Guastello, Chaos, catastrophe, and human affairs: applications of nonlinear dynamics to work, organizations, and social evolution, New York-London 2009 [1995].

33 Zob. E. Morin, Introduction à la pensée complexe, Paris 2005.

34 D. Byrne, Complexity theory and the social sciences. An introduction, London 1998, s. 167. 
wprawdzie budować go da się wyłącznie z zasobów odziedziczonych, ale idee generujące projekt wywodzą się z odczytań teraźniejszości.

Dochodzę w ten sposób do dwu wniosków. Pierwszy narzuca się sam: w świetle tych rozważań bezpieczniej będzie używać pojęć starych, próbując ich redefinicji, to znaczy uświadamiając sobie zmienność sensów i konfrontując się z ryzykiem niezrozumienia. Drugi nie jest tak oczywisty, ale uważam go za praktyczny. Odnosi się do przyjęcia systemowego obrazu świata, a więc odwołania do zobiektyzowanej terminologii proponowanej w ogólnej teorii systemów (GST). Wniosek taki nie może dziwić w moich ustach ${ }^{35}$. Chciałbym jednak dodać kilka słów objaśnienia i uzasadnienia.

Zasadniczym pojęciem, jakie oferuje GST, jest Transformacja, zbiór zasad sterujących zmianami. W szczególności ważne są Nowe Transformacje odpowiedzialne za przekształcenia struktur, a w konsekwencji za tożsamość systemu. W tym ujęciu nie posłużą nam pojęcia imperializmu, kolonializmu i globalizmu, ponieważ są to zagregowane zbiory konkretnych zjawisk, idee mające usprawnić komunikację. Podejmując się zadania czy to z zamiarem dokonania zmiany, czy zwłaszcza chcąc zinterpretować jakąś rzeczywistość (stan jakiegoś systemu), musimy dokładnie określić, zidentyfikować wszystkie zjawiska i procesy, które mają mieć zastosowanie. W praktyce konkretne decyzje, wdrażane rozwiązania technologiczne i organizacyjne, alokacje środków oraz argumenty mające przekonać ludzi do jakiejś polityki nie zawsze są precyzyjnie określone i w pełni świadome. Jako przykład może służyć tak zwana Wielka Transformacja, czyli próba zmiany stanu Polski po 1989 roku, albo dowolny proces do niej należący, taki jak zmiana własności w sektorze produkcji przemysłowej ${ }^{36}$. Możemy jednak odwołać się do mikroskali, jaką stwarza analiza tekstu literackiego albo podobnego świadectwa jakiegoś zjawiska. Nie jestem pewien, czy gdybym chciał przeprowadzić analizę choćby Puszczy Józefa Weyssenhoffa i/albo indyjskich utworów V.S. Naipaula, zaczynając od India: A Wounded Civilization, a kończąc na India. A Million Mutinies Now, powinienem używać tego samego instrumentarium. W obu przypadkach wykorzystanie omawianych pojęć może się narzucać albo być wymagane. W moim przekonaniu będzie dopuszczalne, jeśli ich „zawartość”, ich zdolność operacjonalizowania, zostanie na wstępie bardzo precyzyjnie określona. Pozostając przy tych przypadkach, do których analizy mógłbym sobie rościć jakieś prawa, pojęcia tytułowe mogłyby znaleźć się w konkluzjach odnoszących konkretny przypadek do uogólnionego obrazu epoki.

Weźmy jednak zupełnie inny przykład, z niejasno określonej dziedziny między antropologią, psychologią, historią i literaturą. Wyobraźmy sobie jakiś egzotyczny kraj, w którym może prowadzimy badania, a może tylko podróżujemy, a przy okazji zadajemy miejscowym ludziom jakieś nurtujące nas pytanie. Szukamy czegoś lub

35 J. Kieniewicz, Wprowadzenie do historii cywilizacji Wschodu i Zachodu, Warszawa 2004, s. 38-40.

${ }^{36}$ Na przykład opisana przez Elizabeth Dunn w jej książce Prywatyzując Polskę. O bobofrutach, wielkim biznesie i restrukturyzacji pracy, Warszawa 2008; A. Karpiński et al., Jak powstawaty i upadały zakłady przemysłowe w Polsce, Warszawa 2013, s. 318. 
kogoś, chcemy coś sobie wyjaśnić, zrozumieć dręczącą zagadkę, wszystko jedno. W efekcie naszych pytań uzyskujemy oryginalną narrację spełniającą nasze oczekiwania, docieramy może nie do jakiejś tajemnicy, ale rozwiązania. Potem jednak analiza naszej zdobyczy przekonuje nas, że zostaliśmy oszukani - choć, jako że słowo to jest emocjonalnie nacechowane, może wypadałoby znaleźć inne, bardziej odpowiadające sytuacji, w której „skolonizowany odpisuje”37. Uzyskana opowieść jest oryginalna, ale zawiera treści wtórne, co więcej pochodzące z przestrzeni naszej kultury. Potomek kolonizatorów dostaje od potomków skolonizowanych produkt będący spreparowaną odpowiedzią na przewidywane zapotrzebowanie. Podobne rzeczy zdarzały się wielokrotnie. Gdy zastanawiam się nad moim własnym doświadczeniem, czuję ochotę użycia tytułowych pojęć, a zarazem doświadczam ich nieadekwatności ${ }^{38}$. Wydaje się więc, że nowe narzędzia opisu powinny powstawać w tego rodzaju okolicznościach.

Potrzebne są pojęcia pozwalające ująć procesy dziejące się w różnych miejscach, angażujące ludzi różnych cywilizacji, uniwersalne, a nie spłycające, precyzyjne, ale sięgające głęboko. Powiedziałbym więc, że nie będą miały zakończeń „-izm”. To znaczy - nie zostaną zapożyczone z jakiegoś już funkcjonującego dyskursu. Nie będą ideologicznie warunkowane. Widziałbym następującą sekwencję:

1. Przemoc/opresja;

2. Uzależnienie/uległość;

3. Izolacja/wykorzenienie.

Na tym wypada zakończyć. Moim celem nie była destrukcja; wyzwania naszego czasu skłaniają do szukania nowych rozwiązań, potrzebujemy niedeformujących narzędzi opisu. W epoce sieci, w zderzeniu z globalnym ociepleniem, wobec wyzwania demograficznego i zagrożeń wyczerpania zasobów, opresja, uległość i wykorzen ie ni $\mathrm{e}^{39}$ wydają się rokować lepiej niż dowolny koncept „neo-” lub „post-”. Nie są to pojęcia nowe - przeciwnie, były już w użyciu, jednak nie nabrały charakteru ideowo określonych kategorii. Są używane w konstruowaniu opisów, stanowią część dyskursów, ale nie stały się ideami samodzielnie kreującymi rzeczywistość. Są to przede wszystkim opisy pewnych stanów, które można adaptować do różnych sytuacji. Takie stanowisko można uznać za konsekwencję podejścia holistycznego, któremu właściwy będzie systemowy punkt widzenia ${ }^{40}$. Całościowość z kolei zakłada

37 Zwrotu tego użył w 1982 Salman Rushdie, „The empire writes back with a vengeance”, The Times, 3.07.1982. Zob. B. Ashcroft, G. Griffiths, H. Tiffin, The empires write back. Theory and practice in post-colonial literatures, London 2002.

38 J. Kieniewicz, „From East African post-colonial tale, back to a formative novel”, [w:] Chasing mythical beasts: the reception of ancient monsters in children's and young adults' culture, red. K. Marciniak, Heidelberg 2020, s. 410-415.

39 Zob. moje studia w Silent intelligentsia. Study of civilizational oppression, Warszawa 2009.

40 "So, a key word in the critical response to the reductionist programme is holism - in summary the view that the whole is greater than the sum of its parts. In discussions of the philosophy of social science, the term 'holism' is not generally used. It is more usual to write of 'emergent properties"', D. Byrne, op. cit., s. 3. 
interdyscyplinarność. W danym przypadku będzie to rozumiane jako odwołanie się do tych dyscyplin naukowych, których zastosowanie wynika $\mathrm{z}$ natury podjętego zagadnienia. Jak to nazwać, nie uciekając się do wytartych, ale powszechnie stosowanych zwrotów? Jest to zarazem pytanie o ideę, która będzie w stanie porwać ludzi do działania w skali świata.

\section{Bibliografia}

Ashcroft, Bill, Gareth Griffiths, Helen Tiffin. 2002. The empire writes back. Theory and practice in post-colonial literatures. London: Routledge.

Bachmann-Medick, Doris. 2012. Cultural Turns. Nowe kierunki w naukach o kulturze. Warszawa: Oficyna Naukowa.

Bakke, Monika. 2010. „Posthumanizm: człowiek w świecie większym niż ludzki”. W: Człowiek wobec natury - humanizm wobec nauk przyrodniczych, red. J. Sokólski, 337-357. Warszawa: Neriton.

Bakuła, Bogusław. 2015. „Europa Środkowo-Wschodnia i jej (post)kolonialny świat”. W: Dyskurs postkolonialny we wspótczesnej literaturze i kulturze Europy Środkowo-Wschodniej. Polska, Ukraina, Węgry, Słowacja, red. naukowa Bogusław Bakuła et al., 13-97. Poznań: Bonami.

Barber, Benjamin R. 2008. Skonsumowani. Jak rynek psuje dzieci, infantylizuje dorostych i połyka obywateli. Warszawa: Muza.

Bauman, Zygmunt. 2000. Globalizacja. I co z tego dla ludzi wynika. Warszawa: PIW.

Beck, Ulrich. 2012. Społeczeństwo światowego ryzyka. W poszukiwaniu utraconego bezpieczeństwa. Warszawa: Scholar.

Buruma, Ian, Avishai Margalit. 2005. Okcydentalizm. Zachód w oczach wrogów. Kraków: Universitas.

Byrne, David. 1998. Complexity theory and the social sciences. An introduction. London: Routledge.

Castells, Manuel. 2007. Wiek informacji: ekonomia, społeczeństwo i kultura, t. 1. Społeczeństwo sieci. Warszawa: PWN.

Dunn, Elizabeth C. 2008. Prywatyzując Polskę. O bobofrutach, wielkim biznesie i restrukturyzacji pracy. Warszawa: Wydawnictwo Krytyki Politycznej.

Eriksen, Thomas H. 2003. Tyrania chwili. Szybko i wolno plynacy czas w erze informacji. Warszawa: PIW. Fukuyama, Francis. 2004. Koniec człowieka. Konsekwencje rewolucji biotechnologicznej. Kraków: Znak. Fukuyama, Francis. 2009. Koniec historii. Kraków: Znak.

Gandhi, Leela. 2008. Teoria postkolonialna. Wprowadzenie krytyczne. Poznań: Wydawnictwo Poznańskie.

Gosk, Hanna. 2016. „Krytyka postzależnościowa — polska odmiana studiów postkolonialnych”. W: Perspektywy postkolonializmu w Polsce, Polska w perspektywie postkolonialnej, Debaty Artes Liberales, t. 10, red. J. Kieniewicz. Warszawa: Uniwersytet Warszawski.

Guastello, Stephen J. 2009 [1995]. Chaos, catastrophe, and human affairs: applications of nonlinear dynamics to work, organizations, and social evolution. New York-London: Psychology Press.

Guzowski, Janusz. 2014. „Transhumanizm — eskapizm czy wizjonerstwo?”, Szkice Humanistyczne 14, nr 1(2): 89-105.

Harari, Yuval N. 2018. Homo Deus. Krótka historia jutra. Kraków: Wydawnictwo Literackie.

Karpiński, Andrzej et al. 2013. Jak powstawały i upadały zakłady przemysłowe w Polsce. Warszawa: Muza.

Kieniewicz, Jan. 1986. Od ekspansji do dominacji. Próba teorii kolonializmu. Warszawa: Czytelnik.

Kieniewicz, Jan. 2004. Wprowadzenie do historii cywilizacji Wschodu i Zachodu. Warszawa: Dialog.

Kieniewicz, Jan. 2014. „Ekohistoryk wobec wyzwań przyszłości”, Przegląd Humanistyczny 1: 65-80.

Miscellanea Posttotalitariana Wratislaviensia 8, 2020

(C) for this edition by CNS 
Kieniewicz, Jan. 2020. „From East African post-colonial tale, back to a formative novel”. W: Chasing mythical beasts. The reception of ancient monsters in childrens' and young adults' culture, red. Katarzyna Marciniak, 410-415. Heidelberg: Universitätsverlag Winter.

Kieniewicz, Jan. 2020. „Identifying local people: a colonial and postcolonial practice in Central Asia”. W: Facing challenges of identification. Investigating identities of Buryats and their neighbor peoples, red. Ivan Peshkov, Kamil Wielecki. Warszawa: Wydawnictwo Uniwersytetu Warszawskiego.

Kieniewicz, Jan. 2021. „Experiences in searching for the identity of a nation”. W: Searching for identity: personal experiences and, ethodological reflections, red. Ayur Zhanaev, Olha Tkachenko, 23-35. Warszawa: Wydawnictwo Uniwersytetu Warszawskiego.

Kłoczkowski, Jacek, red. 2000. Antykomunizm po komunizmie. Kraków: Ośrodek Myśli Politycznej.

Kola, Adam F. 2018. Socjalistyczny postkolonializm. Rekonsolidacja pamięci. Toruń: Wydawnictwo Naukowe UMK.

Koselleck, Reinhart. 2009. „Historia pojęć i pojęcie historii”. W: Dzieje pojęć. Studia z semantyki i pragmatyki języka społeczno-politycznego. Warszawa: Oficyna Naukowa.

Kubiaczyk, Filip. 2013. Nowoczesność, kolonialność i tożsamość: perspektywa latynoamerykańska. Poznań: Wydawnictwo Naukowe UAM.

Lohr, Steve. 2015. Data-ism. The revolution transforming decision making, consumer behavior, and almost everything else. New York: HarperCollins.

Loomba A. 2011. Kolonializm/postkolonializm. Poznań: Wydawnictwo Poznańskie.

Martin, Hans P., Harald Schumann. 2000. Pułapka globalizacji. Atak na demokrację i dobrobyt. Wrocław: Wydawnictwo Dolnośląskie.

Mignolo, Walter D. 2002. „Posoccidentalismo: las epistemologías fronterizas y el dilema de los estudios (latinoamericanos) de área", Revista Iberoamericana 68, nr 200: 679-696.

Morin, Edgar. 2005. Introduction à la pensée complexe. Paris: Seuil.

Osterhammel, Jürgen. 2013. Historia XIX wieku. Przeobrażenie świata. Poznań: Wydawnictwo Poznańskie.

Said, Edward. 1978. Orientalism. New York: Pantheon.

Sen, Amartya. 1999. Rozwój i wolność. Poznań: Zysk i S-ka.

Szymański, Kamil. 2015. „Transhumanizm”, Kultura i wartości 13: 133-152.

Todorov, Tzvetan. 2003. Nowy nieład światowy. Refleksje Europejczyka. Warszawa: Dialog.

Toffler, Alvin i Heidi. 1996. Budowa nowej cywilizacji. Polityka trzeciej fali. Poznań: Zysk i S-ka.

Walia, Shelley. 2004. Edward Said y la historiografía. Barcelona: Editorial Gedisa.

Wallerstein, Immanuel. 2007. Analiza systemów-światów. Wprowadzenie. Warszawa: Dialog.

Wallerstein, Immanuel. 1999. The end of the world as we know it. Social science for the twenty-first century. Minneapolis-London: University of Minnesota Press.

Young, Robert J.C. 2012. Postkolonializm. Wprowadzenie. Kraków: Wydawnictwo UJ.

Przyjęto do druku/Accepted for publication: 10.03 .2020

Miscellanea Posttotalitariana Wratislaviensia 8, 2020

(C) for this edition by CNS 